Agro-Science Journal of Tropical Agriculture, Food, Environment and Extension Volume 17 Number 2 (May 2018) pp. $37-44$

ISSN 1119-7455

\title{
EVALUATION OF THE NUTRITIONAL COMPOSITION OFTHE SEEDS OF SOME SELECTED AFRICAN YAM BEAN (SPHENOSTYLIS STENOCARPA HOCHST EX. A. RICH (HARMS)) ACCESSIONS
}

\author{
Baiyeri, S.O. ${ }^{1,2,5}$, Uguru, M.I. ${ }^{1}$, Ogbonna, P.E. ${ }^{1}$, Samuel-Baiyeri, C.C.A. ${ }^{3}$, \\ Okechukwu, $\mathbf{R}^{4}$., Kumaga, F.K. ${ }^{5}$ and Amoatey $\mathbf{C}^{5}$ \\ ${ }^{1}$ Department of Crop Science, University of Nigeria. Nsukka \\ ${ }^{2}$ Department of Crop Science and Horticulture, Federal University Oye-Ekiti, Ekiti State, \\ ${ }^{3}$ Department of Home Science, Nutrition and Dietetics, University of Nigeria. Nsukka \\ ${ }^{4}$ International Institute of Tropical Agriculture (IITA) Ibadan, Nigeria \\ ${ }^{5}$ Department of Crop Science, University of Ghana, Legon \\ Correspondence author mail: baiyerisamuel@gmail.com
}

\begin{abstract}
African yam bean $(A Y B)$ is an important but neglected and underutilized crop producing edible seeds and tubers. The poor awareness of the nutritional values of AYB constitutes one of the major problems limiting its utilization. This study was, therefore, carried out to determine the nutritional potentials of five accessions of African yam bean (TSs 125, TSs 116, TSs 86, TSs 69 and TSs 60) by analyzing their proximate composition and micronutrients (Iron (Fe), Zinc (Zn) and Selenium (Se)). The experiment was laid out in completely randomized design (CRD) with three replications. The results obtained showed significant $(p<0.05)$ variations in the proximate composition of the AYB accession. The crude protein was in the range of 21.84-23.41 \%, crude fat 3.40-3.86 \%, fibre 6.17$6.76 \%$, carbohydrate $52.8-54.48 \%$, dry matter 90.42 - 90.6\%, ash $4.22-4.35 \%$, and moisture 9.4 $9.58 \%$.The Se concentration varied from $312 \mathrm{mg} / 100 \mathrm{~g}$ in TSs 116 to $58 \mathrm{mg} / 100 \mathrm{~g}$ in TSs 60 while Fe ranged between $10.40 \mathrm{mg} / 100 \mathrm{~g}$ in TSs 60 and $6.07 \mathrm{mg} / 100 \mathrm{gin}$ TSs 86 . Zinc varied between 8.83 $\mathrm{mg} / 100 \mathrm{~g}$ in TSs116 and $6.37 \mathrm{mg} / 100 \mathrm{~g}$ in TSs 69.TSs 116 was best accession in terms of crude protein, dry matter, ash, selenium and zinc, while TSs 60 was best in terms of iron. The study revealed AYB seeds as a food crop rich in protein, carbohydrate, fibre, selenium, iron and zinc. The genotypic variability can be exploited in developing African yam bean varieties with better qualities in terms of nutrient density.
\end{abstract}

Keywords: Neglected, underutilized, nutrient-dense, micronutrient and protein

\section{INTRODUCTION}

Protein - energy malnutrition and micronutrient deficiencies ("hidden hunger") are serious health issues globally, especially in the developing countries, including Nigeria. About 14 million people $-8.5 \%$ of the total Nigerian population - are undernourished (FAO, 2012). In Nigeria, in addition to lack of protein and energy, a major cause of undernutrition is inadequatemicronutrients such as vitamin $\mathrm{A}$, iodine, iron, and zinc. Almost 63\% of the Nigerian women are anaemic and $31 \%$ are iodine deficient, while close to $30 \%$ of under-fives are vitamin A deficient and 20\% are zinc deficient (Micronutrient Initiative, 2013; FMH, 2014). High under-five mortality rate; 158 per 1,000 live births has been recorded for Nigeria, with malnutrition accounting for $53 \%$ of these deaths (UNICEF, 2011). These nutritionally-related problems are more prevalent among the resource-poor living in the rural areas and poor city dwellers, because they cannot afford balanced diets. Zinc plays an important role in insulin action, carbohydrate and protein metabolism (Lee et al., 2005). The administration of zinc, magnesium, selenium, vitamin $\mathrm{A}$ and vitamin E improves tissue response to insulin and increases the efficacy of drugs which act through this pathway (Gunasekera et al., 2011). Studies showed higher $\mathrm{Zn}$ deficiency in diabetic adults compared to normal adult subjects (Lee et al., 2005 and Yoon and Lee 2007). Lower plasma selenium concentration was also reported in diabetic patients, women

Please cite as Baiyeri, S.O., Uguru, M.I., Ogbonna, P.E.' Samuel-Baiyeri, C.C.A.' Okechukwu, R., Kumaga, F.K. and Amoatey C (2018) Evaluation of the nutritional composition ofthe seeds of some selected African yam bean (sphenostylis stenocarpa hochst ex. a. (harms)) accessions Agro Science 17 (2) 37 - 44 DOI: https://dx.doi.org/10.4314/as.v17i2.5 
with gestational diabetes, and those with pancreatitis (Kornhauser et al., 2008, Quilliot et al., 2011 and Al-saleh et al., 2004). Zinc, together with these other minerals and vitamins are, therefore, crucial in reducing the incidence of type II diabetes or in its management. Iron facilitates the oxidation of carbohydrates, proteins and fats (Aremu et al., 2005) and aids haemoglobin in the transport of oxygen. It is also an important component of the cytochromes that function in cellular respiration (Soetan et al., 2010). Iron is involved in the synthesis and packaging of important neurotransmitters for brain function (Beard, 2001). Iron deficiency has been reported for varying degrees of impairment in cognitive performance, lowered work capacity, lowered immunity to infections, pregnancy complications e.g. babies with low birth weight, poor learning capacity and reduced psychomotor skills (Batra and Seth, 2002). The consumption of foods rich in iron, zinc, selenium and other vital micronutrients is, therefore, important to the human wellbeing.

Legumes have been noted as a major source of protein, complex carbohydrates and minerals in developing countries. Legumes are also low in fat, do not have cholesterol and are rich in other dietary components such as dietary fibre, which is important in weight management and in regulating blood cholesterol and sugar. Coupled with their nutritional superiority, legumes have also been ascribed economic, cultural, physiological and medicinal roles owing to their possession of beneficial bioactive compounds (Philips, 1993). These useful bioactive compounds in legumes have hypocholesterolemic, antiatherogenic, anticarcinogenic and hypoglycemic properties (Ndidi et al., 2014) Neglected and underexploited indigenous legumes such as African yam bean (AYB) have especially been receiving increasing attention and currently being explored due to their huge nutritional and health potentials. African yam bean produces both edible seeds and tubers. It originated in Ethiopia, but both wild and cultivated types now occur in tropical Africa as far as Egypt and also throughout West Africa from Guinea to southern Africa (Busson, 2001). The seeds are highly proteinous and capable of growth in marginal areas where other pulses fail to thrive (Okpara and Omaliko, 1995). Uguru and Madukaife (2001) reported higher values of lysine and methionine in AYB seeds than in pigeon pea, cowpea and Bambara ground nut. African yam bean is also valued for its satiety over several hours after consumption, especially among farmers and the resource-poor. African yam bean, thus, has high potential to contribute to curbing hunger, and alleviating protein and micronutrient malnutrition in sub-Saharan Africa, if grown on a large scale. In ethnomedicine, AYB is indicated for managing diabetes and high blood pressure. It is used for curing mumps in Benue State, Nigeria, and suggests that African yam bean has some phytochemicals, minerals and antioxidants that have some positive physiological actions and/or pharmacological effects. Five elite African yam bean accessions were therefore analyzed for their proximate composition, iron, zinc and selenium concentrations, with the view of creating more awareness of the nutritional and health benefits of this crop.

\section{MATERIALS AND METHODS}

Thirty six African yam bean accessions were evaluated in a potted experiment at the University of Ghana Department of Crop Science teaching and research farm. The experiment was laid out in completely randomized design (CRD) with three replications. The seeds were planted in May, 2015 and harvested in December, 2015. Thirty two out of these 36 accessions were collected from the Genetic Resources Center of the International Institute of Tropical Agriculture, (IITA), Ibadan Nigeria (Table 1). Five elite African yam bean accessions (TSs 125, TSs 116, TSs 86, TSs 69 and TSs 60) among the IITA accessions were selected for this study based on their yield (unpublished data). The seeds of these five high yielding African yam bean accessions in three replicates were analyzed for micronutrients: $\mathrm{Fe}, \mathrm{Zn}, \mathrm{Se}$ and proximate composition.

\section{Methods}

\section{Sample Preparation}

Extraneous materials and bad seeds were handpicked out of the seeds of the selected five African yam bean accessions. The clean seeds were ground into fine flour using electric mill.

\section{Proximate Analysis}

The seeds of the Africa yam bean accessions were analyzed for proximate composition using AOAC (2005) methods.

\section{Crude Protein (CP) Determination}

Crude protein in the samples was determined by the semi-micro Kjeldahl technique which consisted of digestion and nitrogen determination using adapted auto-analyzer method. Digestion: African yam bean flour sample $(0.5 \mathrm{~g})$ was weighed into the Kjeldahl digestion tubes; 1 Kjedahl catalyst tablet and $10 \mathrm{ml}$ of concentrated $\mathrm{H} 2 \mathrm{SO} 4$ was added to the 
tubes and the contents digested in a fume cupboard for 4 hours until a colourless solution was left in the tube. The digest was cooled and carefully transferred into a $100 \mathrm{ml}$ volumetric flask; the flask was made up to $100 \mathrm{ml}$ with distilled water. One millilitre $(1 \mathrm{ml})$ of the standard solution (digest) was dispensed from the $100 \mathrm{ml}$ into a test tube. Four milliliters (4 $\mathrm{ml}$ ) of the diluent was added and thoroughly mixed. After mixing, $1.5 \mathrm{ml}$ of potassium phosphate tartrate and mixed, then $2.5 \mathrm{ml}$ of alkaline phenate was added and also thoroughly mixed. Lastly, $1.5 \mathrm{ml}$ of commercial bleach (JIK) was added and mixed thoroughly. The solution was left for 30 minutes and read on Atomic Absorption Spectrophotometer (AAS), Buck Scientific Model: Buck 210VG at a wavelength of 630 nm. Calibration curve was used to determine the nitrogen content. A value of 6.25 was multiplied with the value of nitrogen to convert it to protein.

\section{Crude fibre determination}

Two grams $(2.0 \mathrm{~g})$ of the flour sample was weighed into a flask and $100 \mathrm{ml}$ of $0.255 \mathrm{~N}$ $\mathrm{H}_{2} \mathrm{SO}_{4}$ added. The mixture was heated under reflux for 1 hour on a heating mantle and filtered through a sieve cloth. The residue was returned to the fibre flask to which $100 \mathrm{ml}$ of $0.313 \mathrm{~N} \mathrm{NaOH}$ was added and heated under reflux for another 1 hour. The mixture was filtered through a fibre sieve cloth and $10 \mathrm{ml}$ of acetone added to dissolve any organic constituent. The residue was washed with 50 $\mathrm{ml}$ hot water on the sieve cloth before it was finally transferred into a crucible. The residue was oven-dried in a crucible at $105^{\circ} \mathrm{C}$, cooled in a desiccator, weighed and a shed in a muffle furnace at $550{ }^{\circ} \mathrm{C}$ for 4 hours followed by cooling in a desiccators and weighing.

The percentage crude fibre was calculated as:

$$
\% \text { Crude Fibre }=\frac{\mathrm{W}_{1}-\mathrm{W}_{2}}{\text { Weight of sample }} \times 100
$$

(where W1is weight of sample residue after oven drying and W2 is weight of residue after ashing)

\section{Moisture content determination}

The weight of an empty moisture can (W0) was taken: two grams ( $2 \mathrm{~g})$ of the AYB flour sample was added to the moisture can and weighed (W1). The sample was dried using hot air drying oven at $105-1100 \mathrm{C}$ to constant weight, cooled in a desiccators and weighed (W2). Percentage moisture content was calculated as:

$$
\% \text { Moisture }=\frac{\mathrm{W}_{1}-\mathrm{W}_{2}}{\mathrm{~W}_{1}-\mathrm{W}_{0}} \times 100
$$

(where W0is weight of empty moisture can, $\mathrm{W} 1$ is the weight of moisture can with sample, W2is weight of moisture can + oven-dried sample to constant weight).

\section{Ash content determination:}

African yam bean flour $(0.5 \mathrm{~g})$ was weighed into a crucible and heated in the muffle furnace at 500-6000C. The sample was cooled in a dessicat or and weighed. The Percentage ash was calculated as:

$$
\% \text { Ash }=\frac{\mathrm{W}_{2}-\mathrm{W}_{0}}{\mathrm{~W}_{1}-\mathrm{W}_{0}} \times 100
$$

(where $\mathrm{W} 0$ is the weight of the empty crucible, W1is the weight of the crucible with sample while W2 is the final weight of the crucible with sample turned ash)

\section{Crude fat determination}

One gram (1 g) of AYB flour sample was weighed into extraction thimble and plugged lightly with cotton wool. The thimble was placed in the extractor fitted with reflux condenser and a $250 \mathrm{ml}$ soxlet flask which had been previously dried in an oven, cooled in adessicator and weighed. The soxhlet flask was filled to $3 / 4$ of its volume with petroleum ether (bpt $40-60{ }^{\circ} \mathrm{C}$ ) and the sample refluxed until extraction was completed after which the flask which contained the fat extracted was removed and dried to a constant weight in an oven at $105{ }^{\circ} \mathrm{C}$. The amount of fat extracted was calculated as:

$$
\% \text { Fat }=\frac{\mathrm{w}_{2}-\mathrm{W}_{0}}{\text { Weight of sample }} \times 100
$$

(w0 - initial weight of dry soxhlet flask, W1 final weight of oven-dried flask + the extracted fat)

\section{Nitrogen free extract (NFE)}

Nitrogen free extract was determined by subtracting the values $\%$ moisture (M), \% crude protein $(\mathrm{CP}), \%$ fat, \% crude fibre $(\mathrm{CF})$ and $\%$ ash from 100 :

$$
\begin{aligned}
\% \mathrm{NFE}= & {[100-(\% \mathrm{M}+\% \mathrm{CP}+\% \text { fat }} \\
& +\% \mathrm{CF}+\% \text { ash })]
\end{aligned}
$$

\section{Determination of minerals}

The minerals were analyzed using AOAC (2005) method. African yam bean sample flour $(0.1 \mathrm{~g})$ was weighed into a clean $125 \mathrm{ml}$ 
conical flask. Four milliliters $(4 \mathrm{ml})$ of concentrated $\mathrm{H}_{2} \mathrm{SO}_{4}$ was added to the sample and the flask swirled carefully to ensure that the entire sample was wet. The contents of the flask were heated in a fume hood, on a hot plate set at 'medium heating'. The flask was removed and cooled. Ten drops of $\mathrm{H}_{2} \mathrm{O}_{2}$ was added slowly to the flask, to avoid vigorous reaction of the contents. The content of the flask was swirled and reheated, followed by cooling, careful addition of another 6 drops of $\mathrm{H}_{2} \mathrm{O}_{2}$ and reheating. Six drops of $\mathrm{H}_{2} \mathrm{O}_{2}$ wasaga in added while cooling until there was a colour change from black to dark brown. The flask with its content was kept on the hot plate and heated for the last time, and six drops of $\mathrm{H}_{2} \mathrm{O}_{2}$ was added while heating. It was cooled for 1015 minutes, the solution became colourless. The content of the flask was finally transferred into a $100 \mathrm{ml}$ volumetric flask and made up to $100 \mathrm{ml}$ with distilled water. The $100 \mathrm{ml}$ extract was used to determine $\mathrm{Fe}, \mathrm{Zn}$ and $\mathrm{Se}$ using PinAAcle 900T (AAS).

\section{Statistical analysis}

Data obtained was subjected to analysis of variance (ANOVA) in CRD. Significance of treatment means was determined by least significance difference at $5 \%$ probability level using GENSTAT 5.0 Release 4.23 Discovery Edition.

\section{RESULTS}

\section{Proximate composition}

Result of the proximate composition for the African yam bean samples revealed a considerable genotypic variation (Table 2). Crude protein varied significantly $(\mathrm{p}<0.05)$ in the samples. TSs 116 was significantly (p < $0.05)$ higher $(23.41 \%)$ in crude protein than the other accessions while TSs 69 was lowest in crude protein content; however this was not statistically $(\mathrm{p}>0.05)$ different from TSs 86 and TSs 60. The crude fat contents of TSs 116 $(3.86 \%)$ and TSs $125(3.79 \%)$ were significantly $(\mathrm{p}<0.05)$ higher than the rest of the AYB accessions while TSs 69 was significantly $(\mathrm{p}<0.05)$ lowest in fat content $(3.4 \%)$. The fiber content of the accessions did not vary statistically $(\mathrm{p}>0.05)$ however the crude fibre content of TSs $86(6.76 \%)$ was numerically higher than those of the other AYB accessions in fibre content. The fibre content of the AYB accessions ranged from $6.17 \%$ to $6.76 \%$. The carbohydrate content of the African yam bean samples also varied significantly $(\mathrm{p}<0.05)$. The carbohydrate content of TSs $69(54.48 \%)$ was significantly $(\mathrm{p}<0.05)$ higher than that of the other accessions, while that of TSs $116(52.80 \%)$ was the least. The AYB samples did not significantly vary in dry matter content, TSs $116(90.60 \%)$ was however numerically higher in dry matter content than the other accessions. The ash content of the seeds did not vary significantly; however the ash content of TSs $116(4.35 \%)$ was numerically higher than that of the other samples. The moisture content of the samples ranged between $9.40 \%$ in TSs 116 and $9.56 \%$ in TSs 60 and were not statistically significant $(\mathrm{p}>0.05)$.

\section{Mineral content}

Table 3 shows the iron, zinc, selenium contents of the African yam bean accessions. The selenium concentration varied from 312 $\mathrm{mg} / 100 \mathrm{~g}$ in TSs 116 to $58 \mathrm{mg} / 100 \mathrm{~g}$ in TSs 60. The zinc concentration in TSs 116 (8.83 $\mathrm{mg} / 100 \mathrm{~g}$ ) was the highest while that of TSs125 (6.57 mg/100 g) was the least. TSs 60 $(10.40 \mathrm{mg} / 100 \mathrm{~g})$ had numerically highest iron content followed by TSs $69(10.17 \mathrm{mg} / 100 \mathrm{~g})$ and TSs $116(9.03 \mathrm{mg} / 100 \mathrm{~g})$ while TSs 86 was least in iron content $(6.07 \mathrm{mg} / 100 \mathrm{~g})$.

\section{DISCUSSION}

African yam bean

The protein content of the samples of the African yam bean accessions in this study was higher than the $10.6-11.7 \%$ reported by Nyananyo and Nyingifa (2011) for African yam bean and agreed with the findings of Eromosele et al. (2008) who reported values of 21-29 \% for the protein content of AYB and within the range of $9.9-23.7 \%$ of protein values reported for AYB by Ameh (2007). It has been shown that any plant food that provides about $12 \%$ of its calorific value from protein is considered a good source of protein (Effiong et al., 2009; Ali 2010). African yam bean with its good balance of high protein and carbohydrate is therefore a promising food crop that can be useful in combating protein-energy malnutrition. Abete et al. (2009) reported a diet with majority of its protein being derived from legumes when compared with other protein-rich diets fed to obese men in eight weeks induced the greatest amount of weight loss.

Table 1: Collection center of the African yam bean seeds

\begin{tabular}{|c|c|}
\hline Accession & Collection Center \\
\hline TSs 116 & GRC IITA \\
\hline TSs 125 & GRC IITA \\
\hline TSs 69 & GRC IITA \\
\hline TSs 60 & GRC IITA \\
\hline TSs 86 & GRC IITA \\
\hline
\end{tabular}



and Amoatey $\mathrm{C}$.

The obese men that ate legumes at least four times a week experienced significant reduction in waist circumference, body mass fat, blood pressure and total cholesterol. According to earlier reports, clinical studies consistently showed that when replacing carbohydrate-rich foods with legumes, legumes reduced postprandial glucose elevations in both diabetic and non-diabetic participants while legumes also in other eleven trials lowered fasting blood glucose (Thompson et al., 2012). This study has revealed that African yam bean is a protein-rich legume. The crude fat (3.4-3.9 $\%$ ) obtained for the African yam bean accessions was lower than the crude fat obtained for the other legumes; such as soya bean $(28.2 \%)$ by Ogbemudia et al. (2017) and groundnut (46.1\%) by Ayoola et al. (2012). Fat and oil in legumes are usually healthy for human consumption because of their unsaturated nature. The low fat content of African yam bean seed makes it a promising food crop for weight management. The low fat content in African yam bean seed enhances the processing of the seeds to flour without going through the defatting stage in flour production. The level of fibre for African yam bean in this study was higher than that in groundnut (2.83 $\%$ ) by Ayoola et al. (2012) but lower than that (10.37- $17.21 \%$ ) in cowpea by Mamiro et al. (2011). Consumption of fibre has been associated with decreasing low-density lipoprotein (LDL) cholesterol, which is a risk factor in atherosclerosis, coronary heart disease, and ischemic stroke, which can also increase the risk of diabetes, cardiovascular diseases, and some other disease conditions. Inclusion of African yam bean and other legumes in meals and their flour in pastries is, therefore, recommended to reduce the incidence of these health problems. The carbohydrate content of the seeds $(52.80-54.48 \%)$ falls within the range $(42.77$ - $62.76 \%)$ reported for Bambara groundnut by Atoyebi et al. (2017), 54.31-59.64 $\%$ for lima beans by Yellavila et al. (2015) and 38.18-56.96 \% for cowpea by Mamiro et al. (2011). Legumes are especially high in resistant starch (RS), generally defined as starch and starch products not digested in the small intestine (Murphy et al., 2008). Legumes also have a low glycemic index (GI) compared with other carbohydrate-rich foods, likely as a result of both their RS and fibre. The low GI of legumes can potentially produce clinically relevant benefits (Messina, 2014). The ash content $(4.22-4.35 \%)$ of the AYB accessions studied agreed with that $(4.30 \%)$ reported for African yam bean by Adamu et al. (2015). The ash content of the AYB accessions studied was lower than that $(5.35 \%)$ obtained for AYB by Chinedu and Nwinyi (2012) but higher than the ash content of common beans (3.26\%), mung bean $(3.82 \%)$, pigeon pea $(3.55 \%)$, black eyed beans $(3.41 \%)$, and soybean $(4.01 \%)$ by Adamu et al. (2015). Since ash content of a seed is the measure of its mineral content of a material (Anhwange et al., 2004), the level of ash recorded in African yam bean suggests it is a good source of dietary minerals. The optimum moisture content for pulses is in the range of $9-$ $12 \%$ to avoid production of mycotoxins and for safe storage. At a moisture level below 10\%, respiration in most food grain almost stops, increasing the grain storage life (Sujeetha, 2014). The moisture content of the AYB accessions analyzed was less than $10 \%$ and falls within the optimum moisture content range for safe storage of pulses. The low moisture and high dry matter content of the AYB seeds analyzed explains why dry African yam bean seeds obtained from pods harvested during the dry season (without any additional drying after harvest) can be stored in polythene bags for several months, at room temperature, without microbial growth and deterioration.

\section{Mineral content}

The result of this study has shown that the accessions analyzed were statistically similar with respect to iron, zinc and selenium. This could have been as a result of high intragenotypic variation which could have been responsible for low inter-genotypic variation, showing that within each genotype, there is high degree of variability which seems to obscure variation among genotypes for the traits of interest. Furthermore, the high coefficient of variation (CV) of the micronutrients ( $\mathrm{Se}$ and $\mathrm{Fe}$ ) and the high out crossing ratio of about $10 \%$ in African yam bean reported by Adewale (2011) may also be indicted for the non-uniformity in the seed samples for each genotype (accession). The higher the $\mathrm{CV}$, the greater level of dispersion around the mean. The lower the value of the $\mathrm{CV}$, the more precise the estimate (In see, 2016)Considering the results, it is however worth noting that the accessions numerically varied with respect to micronutrients analyzed and that the African yam bean seeds were relatively higher in micronutrients than some of the edible legumes.

The iron contents of the AYB accessions in this study $(6.07-10.40 \mathrm{mg} / 100 \mathrm{~g})$ and zinc contents $(6.57-8.83 \mathrm{mg} / 100 \mathrm{~g})$ were higher than that $(3.10 \mathrm{mg} / 100 \mathrm{~g})$ reported for $\mathrm{Fe}$ and that $(5.0 \mathrm{mg} / 100 \mathrm{~g})$ reported for $\mathrm{Zn}$ in groundnut by Badau et al. (2013). 
Table 2: Proximate composition of the African yam bean accessions (\%)

\begin{tabular}{llllllll}
\hline Accession & Crude protein & Fat & Fibre & Carbohydrate & Dry matter & Ash & Moisture \\
\hline TSs 116 & $23.41 \mathrm{a}$ & $3.86 \mathrm{a}$ & 6.17 & $52.80 \mathrm{a}$ & 90.60 & 4.35 & 9.40 \\
TSs 125 & $23.12 \mathrm{a}$ & $3.79 \mathrm{a}$ & 6.32 & $52.99 \mathrm{a}$ & 90.51 & 4.29 & 9.49 \\
TSs 69 & $21.84 \mathrm{~b}$ & $3.40 \mathrm{~b}$ & 6.52 & $54.48 \mathrm{~b}$ & 90.45 & 4.22 & 9.55 \\
TSs 86 & $21.96 \mathrm{~b}$ & $3.44 \mathrm{~b}$ & 6.76 & $54.04 \mathrm{~b}$ & 90.43 & 4.23 & 9.57 \\
TSs 60 & $21.95 \mathrm{~b}$ & $3.47 \mathrm{~b}$ & 6.57 & $54.11 \mathrm{~b}$ & 90.42 & 4.31 & 9.58 \\
Grand mean & 22.46 & 3.59 & 6.47 & 53.68 & 90.48 & 4.28 & 9.52 \\
LSD $(0.05)$ & 0.813 & 0.255 & NS & 0.993 & NS & NS & NS \\
\hline
\end{tabular}

NS: Non significant at $5 \%$ probability level. \%: percentage

Table 3: Mineral composition of the African yam bean accessions (mg /100 g)

\begin{tabular}{|c|c|c|c|c|c|c|}
\hline Accession & Selenium & Selenium CV (\%) & Zinc & Zinc CV (\%) & Iron & Iron $\mathrm{CV}$ \\
\hline TSs 116 & 312 & 69.07 & 8.83 & 14.78 & 9.03 & 82.13 \\
\hline TSs 125 & 103 & 32.14 & 6.57 & 13.31 & 8.67 & 65.28 \\
\hline TSs 69 & 144 & 99.09 & 6.37 & 17.37 & 10.17 & 26.69 \\
\hline TSs 86 & 133 & 7.69 & 8.42 & 46.54 & 6.07 & 5.80 \\
\hline TSs 60 & 58 & 90.32 & 7.90 & 26.52 & 10.40 & 89.40 \\
\hline Grand mean & 150 & & 7.62 & & 8.87 & \\
\hline $\operatorname{LSD}(0.05)$ & NS & & NS & & NS & \\
\hline
\end{tabular}

NS: Non significant at $5 \%$ probability level

They were also higher than that (1.11 $\mathrm{mg} / 100 \mathrm{~g}$ ) reported for $\mathrm{Fe}$ and $(4.07 \mathrm{mg} / 100 \mathrm{~g})$ reported for $\mathrm{Zn}$ in soya bean by Oluyemi et al. (2005).

The iron and zinc contents of the seeds also indicate that African yam bean is a good dietary source of iron and zinc. The selenium level in the AYB seeds in this study (58-312 $\mathrm{mg} / 100 \mathrm{~g}$ ) indicates that African yam bean seed is a rich source of selenium compared to the selenium levels (5.06-5.08 $\mathrm{mg} / 100 \mathrm{~g})$ reported for Bambara groundnut and (1.31$3.68 \mathrm{mg} / 100 \mathrm{~g}$ ) reported for breadfruit (Ujowundu, 2013). Selenium is an essential trace element for humans and animals and has been reported too low in food produced in most of Europe, parts of Africa, Asia and New Zealand (Haug et al., 2007). Selenium deficiency diseases are not commonly reported but the daily $\mathrm{Se}$ intake is lower than the recommended Rayman (2004). Increasing the Se consumption in human diet can therefore be achieved by the consumption of plants that naturally contain more Se than others (Haug et al. 2007). This study has identified promising AYB genotypes superior for nutrient quality traits analyzed. TSs 116 was best accession in terms of crude protein, dry matter, ash, selenium and zinc while TSs 60 was best in terms of iron. African yam bean seed is recommended for inclusion in human food preparation and consumption. It is also recommended for inclusion in fish and livestock feed meals and as meat alternative for vegetarians. The genotypic variability with respect to these traits could be explored by breeding programs in developing improved
African yam bean varieties with better qualities in terms of nutrient density.

\section{CONCLUSION}

The results of this study showed that African yam bean accessions were rich in protein, carbohydrate, fibre, iron, zinc, selenium, had high dry matter content and low in fat. African yam bean has great potentials for combating protein-energy malnutrition and mitigating the effects of iron, zinc and selenium deficiencies and maintain healthy metabolic processes. Efforts should therefore be made towards increased production and consumption of African yam bean. The result of this study has revealed there is an evident genotypic variability in the AYB accessions analyzed for proximate quality and micronutrients and should be explored in developing improved varieties with enhanced nutritional qualities.

\section{ACKNOWLEDGEMENT}

European Union is appreciated for funding this research through the TRECC Africa PhD Exchange Fellowship offered Baiyeri Samuel.

\section{REFERENCES}

Abete I. Parra D. and Martinez J.A. (2009). Legume-, fish-, or high-protein - based hypocaloric diets: effects on weight loss and mitochondrial oxidation in obese men. J. Med Food., 12 (1), 100-108

Adamu G.O.L. Ezeokoli O.T, Dawodu A.O. Adebayo-Oyetoro A.O. and Ofodile L. N. (2015). Macronutrients and micronutrients profile of some underutilized beans in Southwestern Nigeria. International Journal of Biochemistry Research and Review., 7 (2), 8089 

and Amoatey $\mathrm{C}$.

Adewale B.D. (2011). Genetic diversity, stability and reproductive biology of frican yam bean. $\mathrm{PhD}$ thesis, University of Agriculture, Abeokuta, Nigeria

Ali A. (2010). A comparative study of nutrients and mineral molar ratios of foods with recommended dietary allowances. Journal of Food Science and Technology.,2, 104-108

Al-Saleh E. Nandakumaran, M. Al-Shammari M. and Al-Harouny A. (2004).Maternal-fetal status of copper, iron, molybdenum, selenium and zinc in patients with gestational diabetes.J. Matern. Fetal Neonatal Med.,16, 15-21

Ameh G.I. (2007). Proximate and mineral composition of seed and tuber of African yam bean Sphenostylisstenocarpa (Hoecst. Ex. A. Rich) Harms)). Asset. 6 (1),1-10

Anhwange B.A. Ajibola V.O. andOniye S.J. (2004). Amino acid composition of the seeds of Moringaoleifera (Lam), Detariummicrocarpum (Guill \& Sperr) and Bauhinia monandra (Linn.).ChemClass Journal.,1, 9-13.

AOAC (2005). Official Methods of Analysis (18thed.) Association of Official Analytical Chemists, Washington D.C., USA

Aremu, M.O. Olonisakin A. Otene I.W. and Atolaiye B.O. (2005). Mineral content of some Agricultural products grown in the middle belt of Nigeria. Oriental Journal of Chemistry., 21 (3), $419-425$

Atoyebi J.O. Osilesi. O. Adebawo O. and Abberton M. (2017). Evaluation of nutrient parameters of selected African Accessions of Bambara Groundnut Vignasubterranea (L.) Verdc.)American Journal of Food and Nutrition.,(5) 3, 83-89

Ayoola P.B. Adeyeye A. and Onawumi O.O. (2012). Chemical evaluation of food value of groundnut (Arachihypogaea) seeds. American Journal of Food and Nutrition.,2 (3), 55- 57

Badau M.H. Abba H.Z. Agbara G.I. and Yusuf A.A. (2013). Proximate composition, mineral content and acceptability of granulated maize dumpling (Dambumasara) with varying proportions of ingredients. Global Advanced Research Journal of Agricultural Science., 2 (1), 07-016

Batra J. and Seth P.K. (2002).Effect of iron deficiency on developing rat brain.Indian Journal of Clinical Biochemistry.,17(2), 108114

Beard J. L. (2001). Iron biology in immune function, muscle metabolism and neuronal functioning. Journal of Nutrition.,131, 56855695

Chinedu S.N. and Nwinyi C.O. (2012). Proximate analysis of Sphenostylisst enocarpa and Voadzeia subterranean consumed in South Eastern Nigeria. Journal of Agricultural Extension and Rural Development., 4 (3), 5762

Effiong G.S. Ibia T.O. and Udofia U.S. (2009). Nutritive and energy values of some wild fruit spices in south eastern Nigeria. Electronic
Journal of Environment Agriculture and Food Chemistry.,8, 917-923

Eromosele C.O. Arogundade L.A. Eromosele, I.C. and Ademuyiwa, O. (2008).Extractability of African yam bean (Sphenostylisstenocarpa)protein in acid, salt and alkaline aqueous media. Food Hydrocolloids, 22,1622-1628

FMH(2014).http://www.health.gov.ng/doc/NSPAN. pdf

Food and Agriculture Organization (2012). The State of food insecurity in the world 2012. economic growth is necessary but not sufficient to accelerate reduction of hunger and malnutrition. FAO, Rome: http://www.fao.org/docrep/016/i3027e/i3027e. pdf

GENSTAT (2003). GENSTAT 5.0 Release 4.23DE, Discovery Edition 1, Lawes Agricultural Trust, Rothamsted Experimental Station

Gunasekara P. Hettiarachchi M. Liyanage C. and Lekamwasam S. (2011). Blood sugar lowering effect of zinc and multivitamin/mineral supplementation is dependent on initial fasting glucose. Journal of Diabetology.,1 (2),1-13

Haug A. Graham R.D. Christophersen O.A. and Lyons G.H. (2007). How to use the world's scarce selenium resources efficiently to increase the selenium concentration in food. Microbial Ecology in Health and Disease.,19, 209-228

Insee

https://www.insee.fr/en/metadonnees/definition /c1366

Kornhauser C. Garcia-Ramirez J.R. Wrobel K. Perez-Luque E.L. Garay-Sevilla, M.E. and Wrobel K. (2008). Serum selenium and glutathione peroxidase concentrations in type 2 diabetes mellitus patients. Prim. Care Diabetes.,2, 81-85

Lee J.H. Lee H.J. Lee I.K. Yoon J.S. (2005). Zinc and copper status of middle- and old-aged womanin type 2 diabetes. The Korean Journal of Nutrition.,38, 56-66

Mamiro P.S. Mbwaga A.M. Mamiro D. Mwanri A.W. and Kinabo J.L. (2011). Nutritional quality and utilization of local and improved cowpea varieties in some regions in Tanzania Journal of Agriculture, Food, Nutrition and Development.,11 (1), 4490-4502

Messina V.(2014). Nutritional and health benefits of dried beans. American Journal of Clinical Nutrition.100, 437-442

Micronutrient Initiative (2013).Nigeria country profile. Retrieved from: http://www.micronutrient.org/english/view.asp ? $\mathrm{x}=596$

Ndidi U.S. Ndidi C.U. Aimola I.A. Bassa O.Y. Mankilik M. Adamu Z. (2014) Effects of processing (Boiling and roasting) on the nutritional and anti-nutritional properties of Bambara groundnuts (Vigna subterranean [L.] erdc.) from Southern Kaduna, Nigeria. Journal of Food Processing.,1-9. DOI: $10.1155 / 20172129$ 
Nyananyo B.L. and Nyingifa A.L. (2011). Phytochemical investigation on the seed of Sphenostylisstenocarpa (Hochst ex A. Rich.) Harms (Family Fabaceae) J. Appl. Sci. Environ. Manage.,15 (3), 419-423

Ogbemudia R.E. Nnadozie Blessing C. and Anuge B. (2017). Mineral and Proximate Composition of Soya Bean. Asian Journal of Physical and Chemical Science., 4 (3), 1-6

Oluyemi E.A. Akinlua A.A. Adenuga A.A. and Odebajo M.B. (2005). Mineral contents of some commonly consumed Nigerian foods. European Journal of Scientific Research.,6 (2), 11-15

Okpara D.A. and Omaliko C.P.E. (1995). Effects of staking, nitrogen and phosphorus fertilizer rates on yield and yield components of African yam bean (Sphenostylis stenocarpa).Ghana Journal of Agricultural Science., 28, 23-28 http://dx.doi.org/10.4314/gjas.v28i1.2004

Philips R.D. (1993). Starchy legumes in human nutrition and culture. Plant Foods and Human Nutrition.,44 (3), 195-211.

Quilliot, D., Dousset, B.; Guerci, B., Dubois, F., Drouin, P. and Ziegler, O. (2001). Evidence that diabetes mellitus favors impaired metabolism of zinc, copper, and selenium in chronic pancreatitis. Pancreas.,22, 299-306

Rayman M.P. (2004). The use of high-Se yeast to raise Se status: how does it measure up? British Journal of Nutrition.,92, 557-573

Soetan, K.O., Olaiya, C.O. and Oyewole, O.E. (2010).The importance of mineral elements for humans, domestic animals and plants: A review. African Journal of Food Science.4 (5), 200-222

Sujeetha, J.A.R.P, Abirami, C.V.K. and Alagusundaram, K. (2014). Bio-intensive safe storage methods for pulses: Review. Jiopest.,7 (1), 98-103

Thompson S.V. Winham D.M. and Hutchins A.M. (2012). Bean and rice meals reduce postprandial glycemic response in adults with type 2 diabetes:a cross-over study. Nutrition Journal., 11:23

Ujowundu C.O. Nwaogu L.A. Ujowundu F.N. andBelonwu D.C. (2013). Effect of gas flaring on the phytochemical and nutritional composition of Treculia Africana and Vigna subterranean. British Biotechnology Journal.,3 (3), 293-304

Uguru M.I. and Madukaife S.O. (2001). Studies on the variability in agronomic and nutritive characteristics of African yam bean (SphenostylisstenocarpaHochst ex. A. Rich Harms). Plant Product Resource Journal. ,6, 10-19

United Nations Children's Fund (UNICEF). (2011). At a glance: Nigeria. Retrieved from: http://www.unicef.org/infobycountry/nigeria_st atistics.html

Yellavila, S.B., Agbenorhevi, J.K., Asibuo, J.Y. and Sampson, G.O. (2015). Proximate composition, minerals content and functional properties of five Lima Bean ccessions. Journal of Food Security, 3 (3), 69-74

Yoon J.S. and Lee J.H. (2007). A suggestion to improve zinc status of type 2 diabetic women: relation among zinc, protein and phytate intake. Journal of Korean Dietetic Association. 13, 301-310 